\title{
Comparative analyses of Human Resource AccountingDisclosure Practices in Nigerian Financial Service and Manufacturingcompanies.
}

\author{
OyewoBabajide Michael ${ }^{1}$ \\ ${ }^{1}$ (School of Business, Department of Accounting, Covenant University, Ogun State, Nigeria)
}

\begin{abstract}
With rapid changes in the business environment, organizations are now looking at intellectual assets such as human resources as unique assets that bring about competitive advantage. In spite of the strategic position that human assets occupy, sufficient attention has not been given to standardizing reporting practices. It is against this backdrop that the research examines human resource accounting practices of financial service and manufacturing firms in Nigeria. By content-analysing the financials of 12-selected companies, human resource accounting disclosure indices were derived. Study variables were subjected to statistical procedures such as ANOVA, T-test and Correlation. The study found out that though human resource accounting disclosure practice index of banks is higher in comparison to manufacturing companies, the difference is not statistically significant. Also, there is a strong positive relationship between human resource accounting disclosure and company size. It was the findings of this research that there is a positive connection between the volume of financials and human resource reporting. To enhance the credibility of financial reports, firms may consider valuing and incorporating human assets in their financial statements. Relevant authorities should look into drawing-up specific financial reporting standard on human resource activities to address problems of arbitrariness in human resource accounting disclosure.
\end{abstract}

Keywords: Financial Reporting, Human Resource Accounting, Intellectual asset, Nigeria, Strategic Management Accounting.

\section{Introduction}

Human resource is one of the intellectual assets of an organization. The new essence of human resource management is strategic. With rapid changes in the business environment, organizations are now increasingly looking at intellectual capital and by extension human resources as the unique asset that can drive superior performance. The strategic utilization of human resources can produce a constant stream of improvements in all aspects of customer value in terms of quality, functionality and timely delivery, while lowering cost at the same time, thereby achieving 'continuous improvement' for the organization. In strategic management accounting, the learning curve effecthelps reduce labour cost directly, while other costs connected to labour (e.g. material cost) are also incidentally reduced.

Interestingly, despite the significant contribution of human assets to contribution to enterprise strategies which eventually lead to the achievement of organizational objectives, little attention has been paid to this class of important firm's asset,evidenced by arbitrariness,non-standardization and lack of regulation in reporting on human capital in financial statements or other media through which stewardship is rendered.

The non-valuation and exclusion of human capital in the financial statements of companies suggests thatthe financials do not present the true and fair view of the state of affairs. Unlike the developed countries replete with researches on human capital, to the best of the researcher's knowledge, there are few studies on human resource accounting in developing countries like Nigeria. To this end, the research therefore attempts to advance the frontiers of knowledge by empirically and comparatively studying human resource accounting disclosure practices (HRADP) of Nigerian companies in the financial service and manufacturing industries. Four research hypotheses, formulated for the purpose of the study and stated in their null form are as follows: $\mathrm{H}_{0}{ }^{1}$ : There is no significant difference in HRADP among banks in Nigeria

$\mathrm{H}_{0}^{2}$ : There is no significant difference in HRADPbetween the Financial and Manufacturing industries in Nigeria $\mathrm{H}_{0}{ }^{3}$ : There is no statistically significant relationship between the size of a company and HRARD practice in Nigeria

$\mathrm{H}_{0}^{4}$ : There is no statistically significant relationship between the volume of annual reports and HRARD practice by Nigerian companies 


\section{Literature Review}

The human asset is the total knowledge, skills, creative abilities, talent, altitudes and belief of an organization workforces as well as values, altitude and belief of the individuals involved[1]. Human resource accounting has also been defined as the system of recording of transactions relating to the value of human resource i.e. the cost of acquisition of their knowledge and utilization of the energy for production of goods and services in the most profitable manner and thereby achieving the organization goals [2].

Human resource accounting disclosure practice (HRADP) could be viewed as the practice of recording, measuring and presenting details of transactions connected to human beings working in an organization such as costs incurred in connection with recruitment,selection, placement, induction,training, development, welfare and remuneration of workers. Accounting and reporting on human capital also involve putting monetary value on the human beings working for an organization. Organizations invest in human resources, like they invest in other resources that are inanimate: it is only intuitively appealing to report investments in the workforce, which is the crux of human resource accounting.

Various theories in the discipline of management exist that emphasize the relevance of human resources. One of such theories is the 4Ss of business made up of skills,surroundings, suppliers and systems. Also,there are $6 \mathrm{Ms}$ of business such as men, money, markets, methods, machines and Materials. Another principle, the 8Ps of business, states that the business resources consist of people,process,policies,procedures,price, promotions, places/plants and products. The three perspectives on business resources (4Ss, 6Ms and $8 \mathrm{Ps}$ of business) all start with a common factor (skills, men and people) which is the human resources. These concepts demonstrate the importance attached to human resources. Realizing the supremacy of the human asset over other assets has implication for strategy formulation by firms. It is the human asset that combines the other business resources in a way that ensure the achievement of specified objectives. The manner business resources are combined will vary from one organization to another, depending on individual business strategies. Whatever strategy an organization adopts, the involvement of human resources is critical to the success of the strategy.

Companies are now focusing on using human asset to advantage as core competence for competition in the business environment. Human resources have strategic importance in organizations. In the face of stiff business competition, innovation,collaboration,continuous improvement,continuous learning andkeeping abreast with changes in the environment are key to survival.All these could be brought about by its human capital, occupyingthe centre piece of an enterprise strategy; they cause productivity and profitability to happen.For some organizations where high level of professionalism is expected(for example chartered accounting,legal,information technology firms), large portion of the workforce is expected to be skilled, with minimal number of unskilled workers. Manufacturing concerns may not be expected to have such magnitude of skilled workersbecause of peculiarities in their operations such as employment of semi-skilled labour to work in production locations/outfits. Comparison of the level of professionalism between firms in the same industry can pinpoint weaknesses or competitive advantage that one firm has over the other[3].

The main reason why human resource accounting have taken a long period to be incorporated in the company's final report is the difficulty or challenge of assigning monetary value to various human asset cost, investment and employees worth[4;5;6;7]. As for the valuation of workforce, there are two methods that have been advocated -- the cost approach and economic value approach. The cost approach is based on the actual cost incurred by the company in relation with employees. The cost used could be the historical cost,opportunity cost or standard cost. The economic value approach considers human resource as asset and tries to identify the future earnings resulting from use of human asset, using the concept of present value. The economic value could be measured using models like Flamholtz model, Lev and Schwartz model, Hekimian and Jones competitive bidding model $[4 ; 6]$.

There have been different arguments for and against human resource accounting. The inability to determine the period of future benefits, the ownership status and inability to amortize human assets on an objective way discourage accounting for human resources. Also, there may be no basis to value commitment to an employer or one's ability to work as a team. If low monetary value is placed on an employee or if the value of the employee is reduced overtime like the principle applicable to amortization of intangible assets, it may have a disastrous effect on the morale of the employee.

The case for Human Resource Accounting(HRA) is that workers may not be owned as such, but the convention of substance over form argues that what matters in transaction is the economic substance not the legal form. Leased assets are recognized in the books despite the fact that they are not owned. Human resource expenditure like training and development are incurred for workers who are in the process of learning and therefore they do not benefit the operations of the year in which the costs are incurred. For that reason it is inconsistency for charging such costs in the year of expenditure. Instead they should be capitalized and amortised over the years expected to benefit from the employee's services[4; $[; 6]$ 
Whereas it is agreeable that amortisation rate are subjective, depreciation rates conventionally applied to tangible assets are mere estimates based on assumptions. If non-current tangible assets could be depreciated, then there is no basis to prohibit capitalization, neither is there any justificationfor non-amortization of human resource expenditure.Empirical researches on human resource accounting abound and these studies have repeatedly justified the need to capitalize human asset and present them in financial statements.Human resource accounting has gained wider application in football business. 18 British football clubs included players in the balance sheet. Most clubs used acquisition cost of player on the transfer market as the valuation method[7;8]. One of the regions where human resource costing and accounting has gained much application is Sweden and the factors that contributed to this are; extensive education in human resource accounting at colleges and universities; Human resource accounting is viewed as a new approach to strategic thinking; human resource accounting is used as a change instrument in shifting from regulated economy to a more market oriented economy [6;9].

The stock market analysts feel that human resource accounting is an investor friendly disclosure as well as assuring the various stakeholders that the business has the right human asset to meet future requirement[10]. Research was carried out to ascertain the connection between the financial performances of publicly quoted companies and human resource accounting disclosure practices. Besides, the study also examined if there were differences in human resource accounting disclosure practices between financial and non-financial sector companies. Using multiple regression analyses, the study found out that there is a positive relationship between financial performances of companies and their human resource accounting disclosure practices[11].

\section{Research Methodology}

A total sample of 12 firms -6 commercial banks and 6 manufacturing companies in the Food subsector based on the Nigerian stock Exchange classification- were selected for content analyses of the annual reports \& accounts for the year 2011. Threeclasses of commercial banks currently exist based on the CBN licensing of banks in November 2010 in the category of regional, national and international banks. 1 regional, 3 national \& 2 international banks were selected for the study.Based on these criteria,the selected banks are: First Bank PLC, GTBank PLC\& Diamond Bank PLC for the internationally licensed banks, Stanbic IBTC PLC \& Eco bank PLC for the nationally-licensed banksand WEMA bank PLC for regionally licensed bank.

The 6 manufacturing companies chosen were selected basedon their size. Theselected manufacturing companies were the six biggest in size. Size was measured based on the market capitalization of ordinary shares of the publicly-quotedcompanies as at August 2013. The companies selected were Nestle PLC; Cadbury PLC; National salt company of Nigeria (NASCON) PLC; Dangote sugar PLC; Flour mills PLC and Honeywell flour PLC.

The size of annual report was measured by the total number of pages of annual reports.

ANOVA statistical technique was used to assess if there is any significant difference in HRADP among the three classes of banksin Nigeria.Independent T-test was used to comparatively analyse if there is any significant difference in HRADP between the Banks and Manufacturing companies. A correlation analysis was carried out to establish if there was any statistically significant relationship between HRADP, Size of companies and Volume of annual report.

In order to develop a measurement scale, thatcomprehensively captures HRADP, for subsequent utilization for content analyses of study company's financials, the review of literatures and universally disclosed items in published annual reports of companies was extensively carried out. This also provided a platform of merging theory with practice in human resource accounting. Thirty (30) human resource accounting disclosure variables were identified and featured in the checklist.

Table: 1 Human Resource Accounting Disclosure Practice Checklist/Measurement Scale

\begin{tabular}{|l|l|}
\hline & \\
\hline 1 & Separate HRA statement \\
\hline 2 & Total Value of Human resource \\
\hline 3 & Number of employees \\
\hline 4 & Human resource policy \\
\hline 5 & Training and development \\
\hline 6 & Management succession plan \\
\hline 7 & Employmentreport \\
\hline 8 & Employee Value added in value added statements \\
\hline 9 & Human resource development fund \\
\hline 10 & Employees/workers fund \\
\hline 11 & Board composition \\
\hline 12 & Directors' Emolument \\
\hline 13 & Retirement benefits policy \\
\hline 14 & Performance Recognition \\
\hline 15 & Superannuation fund \\
\hline
\end{tabular}




\begin{tabular}{|l|l|}
\hline 16 & Other employees benefits \\
\hline 17 & Staff cost \\
\hline 18 & Employment of disabled person \\
\hline 19 & Health, safety \& environment at work \\
\hline 20 & Employee involvement \\
\hline 21 & Directors' Profile \\
\hline 22 & Gratuity provision/payment to staff \\
\hline 23 & Pension policy \\
\hline 24 & Pension provision/ payment \\
\hline 25 & Range of emolument-excluding pension- received by employees \\
\hline 26 & Range of emolument received by Directors \\
\hline 27 & Disclosure on diversity \& non-discriminatory practices in employment \\
\hline 28 & Number of persons employed, detailed per division/department \\
\hline 29 & Human rights and labour practices disclosure \\
\hline 30 & Remuneration policy for Directors \& Employees \\
\hline
\end{tabular}

\section{Source: Constructed by the researcher}

The published accounts of sample companies were scrutinized for each of the items for disclosure: scorel is assigned if any of the parameters is found while score 0 is assigned if an item is not found.The HRADP index was thereafter derived for each company wasobtained as follows:

HRADP index $=$ Total score obtained by individual firm x 100/ Total score obtainable

\section{Reliability of data}

Data were sourced from the published annual reports and accounts of companies.

Considering that the published reports were audited by external auditors and approved by the Securities and Exchange Commission (SEC), the Nigerian Stock Exchange (NSE) and the Central bank of Nigeria (CBN) for banks, this is adjudged to provide credibility and the reliability forthe data.

\section{Discussion Of Findings}

This section presents and discusses the HRADP score of each company and the results of statistical procedures performed.The score of the institutions are presented as follows:

Table 2: HRADP score in the Banking Sector

\begin{tabular}{|l|l|l|l|l|l|l|}
\hline & First Bank & GTBank & WEMA & Stanbic IBTC & EcoBank & Diamond \\
\hline $\begin{array}{l}\text { HRARD } \\
\text { score }\end{array}$ & 23 & 23 & 22 & 21 & 18 & 21 \\
\hline $\begin{array}{l}\text { HRARD Index } \\
\text { (in \%) }\end{array}$ & 77 & 77 & 73 & 70 & 60 & 70 \\
\hline $\begin{array}{l}\text { Size of annual reports \& } \\
\text { accounts }\end{array}$ & 288 & 183 & 140 & 109 & 89 & 97 \\
\hline
\end{tabular}

Table 3:HRADP score in the Manufacturing Sector

\begin{tabular}{|l|l|l|l|l|l|l|}
\hline & Nestle & NASCON & Unilever & Honey well flour & Dangote sugar & $\begin{array}{l}\text { Flour } \\
\text { mills }\end{array}$ \\
\hline HRARD score & 25 & 19 & 22 & 15 & 22 \\
\hline HRARD Index (in \%) & 83 & 63 & 73 & 50 & 18 \\
\hline $\begin{array}{l}\text { Size of annual reports \& } \\
\text { accounts }\end{array}$ & 109 & 40 & 43 & 25 & 60 & 59 \\
\hline
\end{tabular}

Table 4: Section of annual report where HRADP is disclosed

\begin{tabular}{|l|l|l|l|l|}
\hline & Section of annual report & Banking Sector & Manufacturing Sector & Total \\
\hline 1 & $\begin{array}{l}\text { Chairman } \\
\text { Statement }\end{array}$ & 3 & 14 & 17 \\
\hline 2 & $\begin{array}{l}\text { Statement of significant } \\
\text { accounting policy }\end{array}$ & 4 & 6 & 10 \\
\hline 3 & $\begin{array}{l}\text { Directors } \\
\text { Report }\end{array}$ & 38 & 34 & 72 \\
\hline 4 & Financial statements \& notes & 59 & 59 & 118 \\
\hline 5 & Corporate governance report & 18 & 7 & 25 \\
\hline 6 & Corporate profile & 1 & - & 1 \\
\hline 7 & $\begin{array}{l}\text { Introduction/Financial } \\
\text { highlights }\end{array}$ & 5 & 1 & 6 \\
\hline & Total & 128 & 121 & 249 \\
\hline
\end{tabular}

The table 4 shows that the highest number of HRADP items was disclosed in the financial statements $\&$ notes for both the financial service and manufacturing companies. This is supported by the result in table 5 which also shows that $55 \%$ of the disclosures were quantitative/numeric data.Financial statements and the notes 
contain mostly quantitative data: it was therefore not surprising that this section of annual reports and accounts captured the highest number of item disclosures. Items disclosed in numeric terms were total number of employees, employees' value addition (value added $\%$ by employee in value added statement, human resource development fund, employees' fund, number of persons on Board, composition of employees (Management \& Non-management staff),details ofdirectors emoluments such as amount, range of emolument, highest paid director, chairman's emolument, staffcost, gratuity provision/payment to staff, pension payment/provision for staff, range of emolument-excluding pension- received by employees, while others in non-numeric terms disclosed in notes to the financial statements were other employees benefits, Pension policy, Disclosure on diversity in employment, pension policy.

The Directors' report also ranks high as per the number of HRADP items disclosed for both industries. Items mostly disclosed in this section were predominantly qualitative/non-numeric such as human resource policy, employee categories, training and development, health, safety \& environment at work, total number of employees, employment of disabled persons, employee involvement, performance recognition, employee involvement, directors' profile, disclosure on diversity \& non-discriminatorypractices, directors' emolumentand human rights and labour practices disclosures.

Management succession plan,directors' profile and remuneration policy for employees \& Board of Directorswere mostly disclosed in the chairman's statement, while board composition was regularly featured in corporate governance report.Majority of sample companiesdisclosed their policy on retirement benefits in the statement of significant accounting policy while few others disclosed it in either the directors' report or notes to the financial statement. Performance recognition was disclosed in either the Chairman's statement or Directors report. Other information such as separate human resource accounting statement, human resource policy and other employees benefitswere disclosed in other reports such as business review andcorporate governance.

On the whole, there were certain items that were disclosed in different parts of the annual reports by different companies. This could be attributable to the non-harmonization of HRADP and also the non-existence of an accounting or any regulatory reporting standard for human resource accounting. Of all the disclosures by Nigeriancompanies, noneplaced monetary value on its entire workforce; there was no use of employee valuation model.This suggests that monetary valuation is not put upon human resources in Nigeria based on the various models for Human resource valuation but the best that is done is the disclosure of qualitative and quantitative information that centre around HRADP.Quantitative information as per investment in human resources is expensed in statement of financial performance (Profit and Loss account).

Also,there was no company that furnished information on Total Value of Human resource,suggesting that none of the HRA valuation model is used. It was only one company that accounted for Human resource development fund. It wasone company as well that disclosed on human rights and labour practices.

Table 5:Numeric/non-numeric disclosures on human resource accounting

\begin{tabular}{|l|l|l|l|l|}
\hline & Disclosure type & Banking Sector & Manufacturing Sector & Total \\
\hline 1 & Quantitative/numeric & 70 & 67 & 137 \\
\hline 2 & Qualitative/non-numeric & 58 & 54 & 112 \\
\hline & Total & 128 & 121 & 249 \\
\hline
\end{tabular}

Nigerian companies in the financial and manufacturing sectors disclose more of quantitative information (representing 55\%) on human resource which supports the findings that the financial statements and its accompanying notes is the section of the annual reports that contains the highest number of items disclosed.

Test of Hypotheses

$\mathrm{H}_{0}{ }^{1}$ : There is no significant difference in HRADP among banks in Nigeria

Table 6:ANOVA test result for hypothesis 1

\begin{tabular}{|c|c|c|c|c|c|}
\hline \multicolumn{6}{|c|}{ ANOVA } \\
\hline Human Resource & ing \& Disclosure Pr & ndex & & & \\
\hline & Sum of Squares & $\mathrm{df}$ & Mean Square & $\mathrm{F}$ & Sig. \\
\hline Between Groups & 10.167 & 2 & 5.083 & 2.128 & .266 \\
\hline Within Groups & 7.167 & 3 & 2.389 & & \\
\hline Total & 17.333 & 5 & & & \\
\hline
\end{tabular}

Table 6 presents the ANOVA result table to test the first hypothesis. Since Sig $>0.266$, we accept the null hypothesis that there is no significant difference in HRADP among banks in Nigeria. This could be attributable to the fact that the financial statements of banks follow a particular trend or pattern because of stringent regulation by the Central Bank of Nigeria. The location of human resource reporting items in the different sections of annual reports is also relatively homogenous, uniform and consistent. 
$\mathrm{H}_{0}{ }^{2}$ : There is no significant difference in HRADP between the Financial and Manufacturing industries in Nigeria

Table 7: Group statistics for Hypothesis 2

\begin{tabular}{|c|c|c|c|c|c|}
\hline \multicolumn{6}{|c|}{ Group Statistics } \\
\hline & Industry & $\mathrm{N}$ & Mean & Std. Deviation & Std. Error Mean \\
\hline Human Resource Accounting \& & Manufacturing & 6 & 20.17 & 3.545 & 1.447 \\
\hline Reporting Practice Index & Financial Service & 6 & 21.33 & 1.862 & .760 \\
\hline
\end{tabular}

Tables 7 and 8 contain the t-test result for hypothesis 2 . The sig value is greater than 0.05 .The null hypothesis is accepted and we conclude that there is no significant difference in HRADP between the Financial and Manufacturing industries in Nigeria. Although the mean score forHRADP in banks is somewhat higher than that of manufacturing companies (this is corroborated by previous research findings in human resource accounting which submitted that financial companies such as banks and insurance companies in Nigeria are disclosing more human resources accounting information than non-financial companies [11]), the difference is not statistically significant.

Table 5 supports the result of t-test that there is no significant difference in HRADP between banks and manufacturing companies. The total number of human resources reporting itemsdisclosed bybank financial institutions is 128 (meaning that on the average, each bank disclosed21 items) while manufacturing companies had 121 items disclosed (an average of 20 items per manufacturing company) which is not statistically different.

$\mathrm{H}_{0}{ }^{3}$ : There is no statistically significant relationship between the size of a company and HRADP in Nigeria $\mathrm{H}_{0}{ }^{4}$ : There is no statistically significant relationship between the volume of annual reports and HRADP by Nigerian companies.

\begin{tabular}{|c|c|c|c|c|c|c|c|c|}
\hline & & $\begin{array}{r}\text { Levene's } \\
\text { Equa } \\
\text { Vari }\end{array}$ & $\begin{array}{l}\text { est for } \\
\text { of } \\
\text { es }\end{array}$ & & & t-test fo & quality of Mea & \\
\hline & & $\mathrm{F}$ & Sig. & $\mathrm{t}$ & $\mathrm{df}$ & $\begin{array}{l}\text { Sig. (2- } \\
\text { tailed) }\end{array}$ & $\begin{array}{c}\text { Mean } \\
\text { Difference }\end{array}$ & $\begin{array}{l}\text { Std. Error } \\
\text { Difference }\end{array}$ \\
\hline \multirow{2}{*}{$\begin{array}{l}\text { Human } \\
\text { Resource } \\
\text { Accounting } \\
\text { Disclosure } \\
\text { Practice } \\
\text { Index }\end{array}$} & $\begin{array}{l}\text { Equal } \\
\text { variances } \\
\text { assumed }\end{array}$ & 3.164 & .106 & $\begin{array}{r}- \\
.714\end{array}$ & 10 & .492 & -1.167 & 1.635 \\
\hline & $\begin{array}{l}\text { Equal } \\
\text { variances } \\
\text { not assumed }\end{array}$ & & & $\begin{array}{r}- \\
.714\end{array}$ & 7.564 & .497 & -1.167 & 1.635 \\
\hline
\end{tabular}

Table 9:Correlation table for hypotheses $3 \& 4$

\begin{tabular}{|c|c|c|c|c|}
\hline \multicolumn{5}{|c|}{ Correlations } \\
\hline & & Company Size & $\begin{array}{c}\text { Human } \\
\text { Resource } \\
\text { Accounting } \\
\text { Disclosure } \\
\text { Practice Index }\end{array}$ & $\begin{array}{l}\text { No of Pages per } \\
\text { Annual Reports } \\
\text { \& Accounts }\end{array}$ \\
\hline \multirow{3}{*}{$\begin{array}{l}\text { Human Resource Accounting } \\
\text { Disclosure Practice Index }\end{array}$} & Pearson Correlation & $.554 *$ & 1 & $.616^{* *}$ \\
\hline & Sig. (2-tailed) & .061 & & .033 \\
\hline & $\mathrm{N}$ & 12 & 12 & 12 \\
\hline
\end{tabular}

Table 9 contains the correlation result for hypothesis 3 and 4 .

Result shows that there is a strong positive relationship between HRADP and company size and it is significant at $10 \%$. Our findings are consistent with the work of other researchers $[11 ; 12 ; 13 ; 14]$.

Companies will generally like to disclose information on human resource in order to keep up with reputation, societal expectation and employment brand $[15 ; 16]$. Corporate organizations will like to pride themselves as choice employer. It is therefore not surprising that a company will make effort to communicate to existing and prospective staff what makes it a desirable place to work and this is achieved through Human resource accounting, reporting and disclosures. The bigger the size of a company, the more it will willingly disclose HRADPto boost employer brand.The relationship between HRADP and Volume of annual reports and accounts is also strong, positive and significant at 5\%. For example, Honeywell Nigeria PLC had the lowestscore of 15 (and a HRADP index of 50\%) in the manufacturing company category which could be attributable to the volume of its 2011 annual report with 25pages. NASCON financials also had a volume of 
40pages and a score of 19.The minimum number of pages for annual report of the banks was 89 pages and the lowest score for HRADP index was $60 \%$ (with a score of 18), meanwhile it was the same bank that had the least volume of annual report that had the lowestHRADPscore.

\section{Conclusion}

The research empirically investigates and compares human resource accounting disclosure practices of banks and manufacturing companies in Nigeria.Findings reveal thatthoughNigerian companies in the financial service and manufacturing industries disclose both qualitative and quantitative, more of quantitative data were disclosed.Banks generally disclosed more on human resources than manufacturing companies but the difference in disclosure was not statistically significant.However, none of the Nigerian companies in the financial and manufacturing industry currently make use of human resource valuation model and as such, the value of human resource is not reported in financial statements, especially the balancesheet.

In order to enhance the expression of the true and fair view of the state of affairs of a company infinancialstatements,companies may consider valuing human resources using the valuation model that suits individual organizational peculiarities and featuring same in the balance sheet, which will lead to better analysis than a conventional balance sheet. There is currently no legislation on reporting human resource practice.This explains the lack of uniformity in the presentation of information on human capital in annual reports.Except the accounting standard on intangible asset (IAS 38)and employee benefit-IAS 19 (employee benefit is only an aspect in human resource accounting), there is no accounting or financial reporting standard that specifically and comprehensively addresses the issue of human resource accounting, reporting and disclosure. In order to address the challenge of lack of standardization for reporting human resource practice, it is recommended that relevant authorities should look into coming up with a financial reporting standard on human resource activities.

\section{References}

[1] Leon C M, Personnel management: A human resources approach. The Irwin series in management and the behavioural sciences (R.D. Irwin; 4th edition, 1981)

[2] Bassi, L., Lev, B., Low, J., and Siesfield, A. Accounting for and measuring the impact of corporate investments in human capital. Paper presented at a conference organised by Brookings Institution held at MIT in January 1998.

[3] Harrell, A.M. and Klick, H.D. Comparing the impact of monetary and non- monetary human asset measures on executive decision making. Accounting, Organizations and Society, Vol. 5, No 4, 1980, 393-400.

[4] Schwarz, J.L., and Murphy, R. E. Human capital metrics: An approach to teaching Using data and metrics to design and evaluate management practices. Journal of Management Education.Vol. 32, No. 2, 2008, 164.

[5] Moore, R. Measuring how 'human capital' appreciates in value over time. Plant Engineering, Vol. 61, No.4, $2007,29$.

[6] Johanson, U. and Nilson, M. (1996). The usefulness of human resource costing and accounting.Journal of Human Resource Costing and Accounting, Vol. 1, No 1, pp. 17-138.

[7] Hendricks, J. The impact of human accounting information on stock investment decisions: An empirical study. Accounting Review Journal, 1976.292-305.

[8] Morrow, S. Football players as human assets. Measurement as the critical factor in asset recognition: A case study investigation. Journal of Human Resource Costing and Accounting, Vol. 1, No.1, 1996.

[9] Olsson, B. Annual reporting practices: information about human resources in corporate annual reports in major Swedish companies. Journal of Human Resource Costing and Accounting, Vol.5, No. 1, 2001.

[10] Jaggi, B., and Lau, S . (1974). Toward a Model for Human Resource Valuation.The Accounting Review, pp.321-29.

[11] EnofeA.O,Mgbame C.,Otuya S. and Ovie C. Human Resources Accounting Disclosures in Nigeria Quoted Firms. Research Journal of Finance and Accounting. Vol.4, No.11, 2013, 156-161

[12] Syed A.A. Human Resource Accounting Disclosure of Bangladeshi Companies and its association with Corporate Characteristics.BRAC University Journal, vol. 6, No. 1, 2009, pp. 35-43

[13] Adams, A., Hill, W. and Roberts, C. Corporate social reporting practices in Western Europe: legitimating corporate behaviour? British Accounting Review, 30, 1996, 1-21

[14] Marston, C. L. and Shrives, P.J (1991). The use of disclosure indices in accounting research: a review article. British Accounting Review, Vol. 25, 1991, 195-210.

[15] Edwards, M. R. An integrative review of employer branding and OB theory .Personnel Review Vol. 39, No.1, 2010, 5-23

[16] Smith, S. and Wheeler, J.A new brand of leadership; Managing the customer experience (UK: FT Prentice Hall, 2002) 